\title{
VALORILE SATULUI ROMÂNESC ŞI IMPORTANTุA LOR MISIONARĂ PENTRU PĂSTRAREA CREDINȚEI ORTODOXE STRĂMOȘEȘTI ÎN DIASPORA ROMÂNEASCĂ
}

Lucian Mircea NiNCU*

\begin{abstract}
The Values of the Romanian Village - Missionary Arguments for Preserving the Ancestral Identity in the Romanian Diaspora ${ }^{1}$. The activity of Orthodox missionaries in the newly established dioceses for Romanian emigrants highlights the sustained work of the Romanian Orthodox mission. This activity must become even more dynamic because the spirituality of the Romanian immigrants is slowly and surely assimilated by the culture of the countries where they migrated, because migration policies aim at the economic and cultural integration of migrants in an extended area of security and justice. Orthodox Missiology will have to resort to novel ways of preaching the gospel of Christ appropriate to the new spiritual space of the Romanian diaspora. To express this missionary process, Orthodox missiology uses the concept of inculturation.
\end{abstract}

Keywords: Romanian village, Orthodox faith, mission, Romanian spirituality, Romanian diaspora.

\section{Introducere: Valorile satului românesc și diaspora românească}

Îndepărtarea geografică și spirituală de locurile natale, de tradițiile și credința strămoșească a emigranților români ortodocși, constituie un motiv suficient şi incontestabil pentru dezvoltarea lucrării misionare a Bisericii Ortodoxe Române în diaspora. Activitatea pe care o desfăşoară

Priest, PhD Student, Faculty of Orthodox Theology at University from Craiova, Romania.

${ }^{1}$ Studiu realizat sub îndrumarea Arhid. Conf. Univ. Dr. Gelu Călina, care și-a exprimat acordul pentru publicare. 
misionarul ortodox în episcopiile nou înființate pentru emigranții români în alte părți ale lumii evidențiază faptul că misiunea ortodoxă românească trebuie să fie permanent lucrătoare. Însă, astăzi, trebuie să vorbim despre o lucrare misionară care trebuie să devină mult mai dinamică, deoarece copiii emigranților români sunt asimilați încet și sigur de cultura țărilor în care au emigrat părinții lor, ceea ce conduce la înstrăinarea acestora de ființa credinței și tradițiilor strămoșești. De aceea, activitatea misionară ortodoxă are nevoie să folosească metode de lucru misionare adecvate noilor realități pentru a se adresa corect diasporei românești. În acest context, satul românesc se constituie, în opinia noastră, într-un concept misionar care poate contribui la realizarea acestei lucrări dumnezeiești. Așadar, scopul prezentei cercetări este să argumenteze modul în care valorile strămoșești ale satului românesc pot contribui la desfășurarea lucrării misionare a Bisericii Ortodoxe Române.

Un model de lucru 1-am identificat în strălucita lucrare misionară bizantină care a contribuit la trezirea credinței şi la păstrarea specificului cultural al neamurilor. Lucrarea misionară bizantină, ca rezultat al implicării unui amplu cerc de oameni: episcopi, preoţi, monahi, împărați, prinți şi prințese, diplomați, ofițeri, soldați, negustori, marinari, emigranţi, călători şi chiar prizonieri politici sau de război, a folosit conceptul misionar de inculturație încă din vremea în care acesta nu era formulat. Traducerea Sfintei Scripturi, a textelor liturgice şi a scrierilor Părinţilor în limbi regionale, ridicarea de lăcașuri de cult și ,preocuparea pentru viaţa ascetico-mistică, care nu a coincis cu un dezinteres faţă de problemele sociale şi culturale ale vieţii"', au imprimat popoarelor cărora a fost vestit pe Hristos propria experienţă politică, artistică, economică şi culturală, și a făcut ca Bizanțul să păstreze în acest fel identitatea şi specificitatea națiunilor respective ${ }^{3}$.

Pentru că după căderea regimului totalitar din România nu au existat programe și politici de stat care să asigure populației certitudini spirituale şi materiale, foarte mulți români, majoritatea creștini ortodocși, au emigrat. Indirect sau poate că nu, înstrăinarea și îndepărtarea lor de tradiţiile și valorile strămoșești ale satului românesc a condus inevitabil

${ }^{2}$ Ciprian Iulian ToroczKaI, Misiunea Bisericii Ortodoxe, ieri și azi, Sibiu, Edit. Astra Museum, 2016, p. 18.

${ }^{3}$ Ibidem, p. 19-20. 
la diluarea responsabilităţii pe care o aveau față de mărturisirea lui Hristos. De aceea realizarea prezentei cercetări are ca scop relevarea importanței pe care o are lumea satului strămoșesc pentru lucrarea misionarului ortodox în păstrarea credinței ortodoxe din diaspora românească.

Potrivit teologilor, istoricilor, filozofilor și sociologilor români, etnogeneza poporului român s-a înfăptuit în spațiul satului strămoșesc. Acesta este motivul pentru care considerăm că prin cunoaşterea geografiei spirituale și culturale a satului românesc de către misionarul ortodox și precizarea acestuia în mentalul emigrantului român ortodox se poate realiza perpetuarea valorilor și principiilor spirituale, morale, culturale, sociale, istorice ale credinței și valorilor românești strămoșești în spațiile culturale în care emigrează ortodoxia cu specific românesc.

\section{Valori spirituale și culturale ale satului românesc}

Pentru ca generațiile viitoare de români din diaspora să perpetueze valorile satului românesc, trebuie ca aceștia să conştientizeze identitatea lor de credința în care să se regăsească și să își exprime ființa lor socioculturală. Sociologic, acestea sunt reprezentate de: religie, stil vestimentar, cultura culinară, felul în care locuiește, spațiul, arhitectura, limba, tradițile populare, arta, comunicarea, modul în care își organizează viața privată și publică, în care relaționează cu alte națiuni și etnii, ș.a. ${ }^{4}$.

În Elogiul satului românesc, discurs pe care Lucian Blaga l-a rostit cu ocazia primirii sale în Academia Română, a tratat despre satul românesc. În viziunea sa, satul românesc are capacități creatoare universale. Pentru el satul românesc este ,singura prezenţă vie încă, deși nemuritoare, deși așa de terestră, este unanimul nostru înaintaș fără nume" 5 .

${ }^{4}$ Dimitrie Gusti, Opere, vol. I, Bucureşti, Edit. Academiei Române, 1968, p. 500 apud Manuela GHEORGHE, „Tradiţia - coordonată fundamentală a religiozității în comunitățile rurale din România", în Revista Română de Sociologie, Anul XV, Nr. 56, 2005, p. 503.

${ }^{5}$ Lucian BlagA, „Elogiul satului românesc, discurs de recepție la Academia Română, susținut în data de 5 iunie 1937”, în vol. Izvoade - eseuri, conferințe, articole, 
Pentru Mircea Eliade, spațiul religios al satului românesc are dimensiuni cosmice, deoarece exprimă relația dintre om și Dumnezeu și are capacitatea de a releva taina întregii existențe ${ }^{6}$. Aici satul este reprezentarea a tot ce este viu, faptele oamenilor reprezintă lucrările lui Dumnezeu și sunt săvârșite pentru că fac parte organică din lucrarea lui Dumnezeu? ${ }^{7}$ În acest context, Biserica reprezintă prin excelență spațiul spiritual în interiorul căruia se structurează întreaga viaţă religioasă a satului, dar satul este și spațiul dintre centrul, care este Biserica și margine, care este cimitirul, adică se desfășoară în realitatea vieții dintre prezența și lipsa lui Dumnezeu ${ }^{8}$, deoarece viaţa în interiorul satului reprezintă trăirea în universul pe care veșnicia îl propune omului ca mod de existenţă absolută9 . Așadar, potrivit istoricului religiilor, în procesul etnogenezei poporului român universalizarea mesajului creștin s-a realizat în spaţiul religios al satului începând cu încreștinarea și păstrarea tradițiilor și obiceiurilor ancestrale precreștine.

Sfânta Tradiție a ortodoxiei românești a mărturisit pe Hristos propovăduind învățătura de credință în contextul procesului de încreștinare a vieții spirituale a satului românesc prin toleranță și conservare și revalorizare a tradițiilor, obiceiurilor și credințelor populare strămoșești. Rolul tradiției este acela de a tezauriza valorile spirituale și de a le transmite de-a lungul generațiilor. Acesta este un argument solid pentru misionarul ortodox și un motiv cert pentru care acesta trebuie să păstreze lucrătoare tradiția în interiorul comunităților de emigranți ortodocși români. Istoria românească arată că în momentele în care românului ortodox i s-au propus elemente diferite de spațiul său spiritual, acesta le-a raportat valorilor sale ancestrale exprimate de tezaurul

Bucureşti, Edit. Minerva, 1972, p. 2, disponibil la: https://condeier.ro/elogiul-satuluiromanesc-lucian-blaga/ (accesat la: 14. 03. 2019).

${ }^{6}$ Dumitru StĂNILOAe, Reflecții despre spiritualitatea poporului român, București, Edit. Elion, 2001, p. 75.

${ }^{7}$ Ernest BERneA, Civilizația română sătească. Ipoteze şi precizări, Colecția „Țară şi Neam", Bucureşti, 1944, p. 55, disponibil la: http://doctorate.ulbsibiu.ro/wpcontent/uploads/BUZAS_REZUMATTEZADOCTORAT.pdf, (accesat la: 14. 03. 2019).

${ }^{8}$ Lucian BLAGA, „Elogiul satului românesc, discurs de recepție la Academia Română, susținut în data de 5 iunie 1937”, p. 5.

${ }^{9}$ Ibidem, p. 6. 
spiritual tradițional și, în acest fel, raportat la propria sa lume sătească, șia păstrat identitatea de credință, de limbă și de neam ${ }^{10}$.

Părintele Dumitru Stăniloae evidenția faptul că țăranul român înţelegea prezenţa harică şi ocrotirea milostivă a lui Dumnezeu ca revărsare a tainicei Sale lucrări în lume: „Vede pe Dumnezeu în taina naturii. Un peisaj frumos al naturii e pentru el un adevărat rai. El spune în Miorița: „Pe un picior de plai,/Pe o gură de rai”"11.

\section{Satul românesc și diaspora românească}

Pentru foarte mulți români din diaspora satul românesc este viu în sufletul lor, ne spune un părinte slujitor în afara granițelor țăriii ${ }^{12}$, însă sunt și mulți care se înstrăinează definitiv de casă. Mulți își iau satul cu ei în suflet și duc mai departe tradițiile strămoșești în mica lor comunitate din diaspora în paralel cu efortul de a se integra în noua cultură. Unii rezistă impulsionați de gândul reîntoarcerii, alții se lasă cuprinşi și fascinați de noua civilizație și se adaptează culturii țării care i-a adoptat: „Sunt destui români la Paris care se gândesc să se întoarcă - cândva în țară, dar atenție!, copiii lor, nu prea. Copiii se simt mai curând francezi"13 , afirmă părintele Răzvan Ionescu. În opinia sa, secularizarea acționează mai rapid asupra copiilor pe care îi desparte de părinți prin adaptarea lor la un mod de viață diferit, ceea ce face ca cei mici să piardă treptat valorile părinților. Ce ne atrage atenția este remarca: „Partea simpatică e că sunt oameni care trăiesc ca în România odată emigrați, iar atmosfera de la biserică e cea de acasă, din sat. Însă nu pretutindeni" 14 .

Părintele are convingerea că tradiția satului românesc e impregnată de simţire creștină, care este încifrată profund în ființa și cultura românească. Satul românesc are forța de a transmite credința

${ }^{10}$ Ibidem.

11 Dumitru StĂnIloAe, Reflexii despre spiritualitatea poporului român, Craiova, Edit. Scrisul Românesc, 1992, p. 105.

12 Gabriela ZamorA, Românii din diasporă şi satul lăsat în urmă, disponibil la: http://ziarullumina.ro/romanii-din-diaspora-si-satul-lasat-in-urma-140855.html, (accesat la 11.03. 2019).

${ }^{13}$ Ibidem.

${ }^{14}$ Ibidem. 
strămoșească. „Avem nevoie de ea. Dea Domnul minte românilor să ịși înţeleagă adevăratele valori!"’15.

Păstrarea autentică a valorilor satului românesc întemeiate pe credința ortodoxă, oferă românilor înțelepciune, simplitate, dragoste față de aproapele, frică de Dumnezeu. De aceea, credem noi, este nevoie ca lucrarea misionară a Bisericii Ortodoxe Române din diaspora să pună accent pe conștientizarea valorilor satului românesc pentru imigranții români ortodocşi, deoarece, dacă valorile care îi educă și formează vin de la televizor și de la supermarket și nu din adâncul de trăire și credință strămoșească autentică, identității diasporei românești îi va fi greu să supraviețuiască.

„Dar dacă are conștiința că propune cel puțin un produs în concurență loială cu celelalte specifice lumii globalizate și postmoderne, «produsul» fiind viața cu specificul ei de țăran român, se poate lupta. Iar dacă cumva ajunge și la conștiința, mult mai înaltă, că viața duhovnicească poartă pe om la maximul de devenire întru umanitate, că este ingredientul vital necesar lumii pentru a moșteni viața veșnică și că satul românesc este prin excelență un vehicul al acestei culturi eshatologice, nu va fi ceva mai important în viața lui decât a-L mărturisi, prin identitatea sa de țăran, pe Hristos. Un astfel de sat populat cu mărturisitori devine un rai care nu poate fi șters de nici o secularizare"16.

\section{Reflecții și concluzii}

Extinderea Uniunii Europene înseamnă deschiderea către o unitate culturală exprimată prin diversitatea limbilor, tradițiilor și obiceiurilor, a curentelor și formelor culturale și artistice, dar mai ales de ecumenicitatea religiei creștine. În acest context, pentru emigrantul român ortodox, satul românesc constituie universul în care au trăit și pe care strămoșii noștri 1au apărat cu cinste. Tradiția și credința că Ortodoxia a reprezentat dintotdeauna țara noastră spirituală, care ne-a dat dreptul să locuim pe acest pământ și sub acest cer, reprezintă valori românești incontestabile pe care Biserica Ortodoxă Română trebuie să le transmită și să le păstreze vii în sufletul diasporei românești. În etnogeneza poporului român, satul

\section{${ }^{15}$ Ibidem. \\ ${ }^{16}$ Ibidem.}


constituie mediul de bază care a contribuit la fundamentarea ideii de paradis etnic românesc, pentru că prin structura lui satul însuşi, ca spațiu terestru, este un paradis etnic în miniatură ${ }^{17}$.

Biserica Ortodoxă Română este răspunzătoare în fața lui Hristos ${ }^{18}$ pentru soarta neamului românesc care i-a fost încredințat spre mântuire. De aceea, misiunea ei în diaspora românească constă în revigorarea duhovnicească a neamului și credinței românești de pretutindeni, în împrospătarea bogăției de interpretări spirituale pentru credincioșii români ortodocşi de mâine și mai ales pentru pregătirea acestora în vederea asimilării influențelor străine de duhul Evangheliei „care ameninţă să ne desființeze ca neam propria noastră ființă" ${ }^{19}$. Numai în aceste condiții credința strămoșească și neamul românesc se va putea îndrepta spre împlinirea dezideratelor spirituale care îi stau în față păstrându-și totodată strălucirea oferită de către Însuși Hristos Domnul prin etnogeneză.

În concluzie, de-a lungul existenţei sale milenare, Ortodoxia românească a fost preocupată de răspândirea credinţei creştine, atât pentru a împlini porunca Mântuitorului Iisus Hristos de a propovădui învățătura Sa tuturor neamurilor (Mt. 28, 19), adică străinilor care se află între granițele sale, cât și de a păstra vie credința strămoșească în inimile românilor care au părăsit spațiul strămoșesc de credință și au emigrat în culturi și tradiții religioase cu dimensiuni spirituale care oferă exprimări inedite în contexte culturale specifice.

Răspunsul pe care misionarul ortodox este chemat să îl ofere acestor provocări, necesită ,,predicarea Evangheliei, nu ca proclamare a unor principii sau adevăruri etice, ci ca început al transfigurării inaugurate de „lumina Evangheliei slavei lui Hristos” (II Cor. 4, 4)"20. Efectuarea unei activităţi misionare sinergice realizată de harul Duhului Sfânt şi participarea personală, în care termenul personal nu reprezintă o lucrare

${ }^{17}$ Ilie Moldovan, ,Valențele spirituale ale agriculturii în etnogeneza poporului român”, în vol. Grai maramureșean și mărturia ortodoxă, Baia Mare, 2001, p. 286.

${ }^{18}$ Cf. „Tomosul de autocefalie al Bisericii Ortodoxe Române”, în BOR, Nr. 5, 1885, p.

346-347 apud Mircea Cristian PRICOP, Tezaurul identitar românesc. O perspectivă teologică inedită, Constanţa, Edit. Arhiepiscopiei Tomisului, 2013, p. 236.

${ }^{19}$ Dumitru StĂniloAe, Reflecții, p. 131.

${ }^{20}$ Ciprian Iulian ToroczKaI, Misiunea Bisericii Ortodoxe, ieri şi azi, p. 21. 
strict individuală, ci, dimpotrivă, implică comunitatea de credinţă, adică Biserica, face referire la prezenţa unei creaţii harice noi care se realizează prin intermediul Sfintelor Taine.

Totodată, pentru emigrantul român, misionarul ortodox trebuie să evidențieze faptul că, potrivit tradiţiei și teologiei ortodoxe, Biserica trebuie să laude pe Dumnezeu prin vocea fiecărei țări, a culturii și identității sale specifice, ceea ce presupune existența unei activități misionare sincere şi corecte față de identitatea de limbă, de credință și față de tradițiile fiecărui popor. $\mathrm{Cu}$ alte cuvinte, sfințirea fiecărui neam înseamnă respectarea și formularea valorilor acestuia, dar şi însumarea într-un imn doxologic comun, ceea ce reprezintă un argument pentru înființarea bisericilor locale într-o Europă a neamurilor.

În ceea ce privește scopul lucrării misionare a Ortodoxiei românești în diaspora, în opinia noastră, valorificarea misionară a satului românesc contribuie, pe de o parte, la realizarea misiunii interne care se adresează fiecărui credincios în parte şi, pe de altă parte, la realizarea lucrării misionare a întregii Biserici. „Conștientizarea faptului că pentru fiecare creștin participarea la misiune este o poruncă existenţială trebuie să se extindă asupra întregii comunități eclesiale, deoarece Biserica nu este doar o încorporare în Hristos, ci este „Trupul lui Hristos” (Efes. 1, 23). De aceea, o Biserică fără misiune este o contradicție în termeni. Biserica a fost trimisă, la fel ca Hristos (Lc. 4, 18, In. 17, 18), să continue lucrarea $\mathrm{Sa}^{\prime 21}$.

\section{Referinţe bibliografice:}

1. BERnEA, Ernest, Civilizația română sătească. Ipoteze şi precizări, Colecţia „Țară şi Neam”, Bucureşti, 1944, disponibil la: http://doctorate.ulbsibiu.ro/wpcontent/uploads/BUZAS_REZUMATTEZADOCTORAT.pdf, (accesat la: 14. 03. 2019);

2. BLAGA, Lucian, „Elogiul satului românesc, discurs de recepție la Academia Română, susținut în data de 5 iunie 1937”, în vol. Izvoade -

21 Anastasios Yannoulatos, Mission in Christ's Way. An Orthodox Understanding of Mission, Holy Cross Orthodox Press, Brookline, Massachusetts/World Council of Churches Publications, Geneva, 2010, p. 50-54 apud Ciprian Iulian ToroczKAI, Misiunea Bisericii Ortodoxe, ieri și azi, p. 23. 
eseuri, conferințe, articole, București, Edit. Minerva, 1972, disponibil la: https://condeier.ro/elogiul-satului-romanesc-lucian-blaga/, (accesat la: 14. 03. 2019).

3. GHEORGHE, Manuela, „Tradiţia - coordonată fundamentală a religiozității în comunitățile rurale din România", în Revista Română de Sociologie, Anul XV, Nr. 5-6, 2005;

4. Moldovan, Ilie, „Valențele spirituale ale agriculturii în etnogeneza poporului român", în vol. Grai maramureșean și mărturia ortodoxă, Baia Mare, 2001, p. 286-301;

5. PRICOP, Mircea Cristian, Tezaurul identitar românesc. O perspectivă teologică inedită, Constanţa, Edit. Arhiepiscopiei Tomisului, 2013;

6. STĂNILOAE, Dumitru, Reflecții despre spiritualitatea poporului român, Bucureşti, Edit. Elion, 2001;

7. StĂniloAe, Dumitru, Reflexii despre spiritualitatea poporului român, Craiova, Edit. Scrisul Românesc, 1992;

8. ToroczKaI, Ciprian Iulian, Misiunea Bisericii Ortodoxe, ieri și azi, Sibiu, Edit. Astra Museum, 2016;

9. ZAMORA, Gabriela, Românii din diasporă și satul lăsat în urmă, disponibil la: http://ziarullumina.ro/romanii-din-diaspora-si-satul-lasatin-urma-140855.html, (accesat la: 11. 03. 2019). 